\title{
Zinc Detoxification by a Cyanobacterium from a Metal Contaminated Bay in Brazil
}

\author{
Luciana Andrade ${ }^{1,2}$, Carolina N. Keim ${ }^{3}$, Marcos Farina ${ }^{3 *}$ and Wolfgang C. Pfeiffer ${ }^{1}$ \\ ${ }^{1}$ Instituto de Biofísica Carlos Chagas Filho; Universidade Federal do Rio de Janeiro; CCS; Cidade Universitária; \\ 21941-590; Rio de Janeiro - RJ - Brazil. ${ }^{2}$ Departamento de Biologia Marinha; Instituto de Biologia; Universidade \\ Federal do Rio de Janeiro; CCS; Cidade Universitária; 21941-590; Rio de Janeiro - RJ - Brazil. ${ }^{3}$ Laboratório de \\ Biomineralização; Instituto de Ciências Biomédicas; Universidade Federal do Rio de Janeiro; CCS; Cidade \\ Universitária; 21941-590; Rio de Janeiro - RJ - Brazil
}

\begin{abstract}
We describe here the trapping of zinc in polyphosphate granules of the cyanobacterium Synechocystis aquatilis NPBS-3. Cells were cultured in $25 \mu M$ of zinc chloride and prepared for electron microscopyand energy-dispersive $X$-ray analysis. Some ultrastructural features were changed by zinc exposure, the increase of glycogen granules number being the main change. The polyphosphate granules contained phosphorus, sulphur, calcium, iron and zinc. The trapping of zinc in polyphosphate granules seemed to be an effective way of detoxifying the metal and surviving in the bay. As a non-specific mechanism, these polyphosphate granules could also be effective in trapping other metals in excess.
\end{abstract}

Key words: Heavy metals, zinc, Sepetiba Bay, polyphosphate granules, glycogen granules, detoxification

\section{INTRODUCTION}

Sepetiba Bay, located southwest of Rio de Janeiro city, Brazil, is a well-known metal contaminated environment. Zinc, cadmium and chromium have been pointed as critical metals (Penna Franca et al., 1984). The cyanobacterium Synechocystis aquatilis NPBS-3 was isolated from phytoplankton samples collected in Sepetiba Bay. The cells have been maintained in laboratory (Universidade Federal do Rio de Janeiro - NPPN culture collection) since then. Investigations of physiological changes due to zinc have been done and differences in growth and photosynthetic rates relatively to control samples have been pointed (Andrade et al., 1993, 1994). More recently, zinc retention by these cells was confirmed by atomic absorption spectrophotometry as 20-fold the control when they grew under $25 \mu \mathrm{M}$ of zinc, the $\mathrm{EC}_{50}$ (effective concentration which causes the inhibition of $50 \%$ of cell growth relatively to control samples) found for the metal (Andrade and Pfeiffer, 1999). These studies have confirmed the cyanobacterium tolerance to zinc.

As a trace element, zinc only becomes toxic to organisms above certain concentrations, in the range of micro or millimolar. This is the case in waters of many metal contaminated environments. As a consequence, metal-tolerant organisms develop as selection takes place (Robinson, 1989). The selection of such organisms is explained by the many metal-detoxification or metal-controlling mechanisms found.

*Author for correspondence 
According to Simkiss (1993), one of the abilities of living systems is to have cells capable of regulate and compartmentalise ions from their surroundings, and this would lead to biomineralization towards the production of amorphous minerals. Among them there are granules containing phosphorus, calcium and magnesium. Their amorphous structure is important for both presumable functions of stocking and detoxifying ions (Taylor and Simkiss, 1993). These minerals have been found in invertebrates and their use as environmental monitors of metal pollution has been suggested (Simmons et al., 1994).

Polyphosphate granules are a common structure in bacteria. They are the bacterial counterparts for the phosphorus granules, and probably these two structures have some similar functions in cells. The elemental composition of the polyphosphate granules of cyanobacteria is, usually, phosphorus, magnesium, potassium and calcium (Baxter and Jensen, 1980a); sometimes, sulphur is also present (Rai et al., 1990).

Here we show the presence of zinc in the polyphosphate granules of the cyanobacterium Synechocystis aquatilis NPBS-3 cultured in $25 \mu \mathrm{M}$ of zinc chloride. Besides, we also show the increase in the number of glycogen granules in these cells.

\section{MATERIALS AND METHODS}

\section{Growth of Synechocystis aquatilis NPBS-3}

Synechocystis aquatilis NPBS-3 cells were grown photoautotrophically and axenically in $1 \mathrm{~L}$ of ASM-1 medium (Gorham et al., 1964). Cultures were maintained at $28^{\circ} \mathrm{C}$ and continuous illumination provided by 2 cool white fluorescent tubes, giving a surface irradiance of $17 \mu \mathrm{Em}^{-2} \mathrm{~s}^{-1}$. Flasks were sparked with sterile air throughout the growth period. $\mathrm{ZnCl}_{2}$ concentrations provided were $3.2 \mu \mathrm{M}$ (control) and $25 \mu \mathrm{M}\left(\mathrm{EC}_{50}\right)$. An

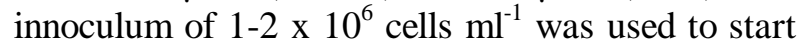
cultures.

\section{Electron Microscopy}

Cells were collected by centrifugation at the end of cultivation period. They were washed 3 times in a small volume of PBS ( $\mathrm{pH} 7.4)$ and centrifuged. Fixation was carried out in $2.5 \%$ glutaraldehyde in
0.1 M cacodylate buffer, $\mathrm{pH}$ 7.4. Post-fixation was done with $1 \%$ osmium tetroxide for one hour. Cells were washed, dehydrated in acetone series and embedded in Polybed 812. Sections were cut with a diamond knife and collected on copper grids. They were then stained in uranyl acetate and lead citrate. Sections were observed under the transmission electron microscopes Zeiss CEM 902 and Zeiss 900.

\section{Energy-Dispersive X-Ray Analysis (EDXA)}

A special specimen preparation was done for Energy-Dispersive X-ray Analysis (EDXA). Small volumes of a very dense culture were collected by centrifugation in a microcentrifuge. ASM-1 medium was taken out and cells were washed with distilled water two times. They were embedded in the hydrophilic resin Nanoplast (Ted Pella, Inc.) for $48 \mathrm{~h}$ at $40^{\circ} \mathrm{C}$ and polymerised for $48 \mathrm{~h}$ at $60^{\circ} \mathrm{C}$. Ultrathin sections were cut with a diamond knife and placed on nylon grids. Analysis was carried out in a Jeol 1200 EX electron microscope operating at $80 \mathrm{kV}$ with a Noran detector system, for 200 seconds. A background spectrum was obtained from a cytoplasm region of the same cell, in the same conditions, and subtracted from the polyphosphate body spectrum.

\section{RESULTS AND DISCUSSION}

Cells were collected at the late exponential period (after 25 days of the innoculum); at this stage a reasonable number of cells could be obtained for electron microscopy and analytical studies. Growth curves for control and zinc-treated cells are presented on Fig. 1.

Micrographs of a control cell and a zinc-treated cell are respectively seen in Figs. 2 and 3. Glycogen and polyphosphate granules are pointed. Looking at the micrographs, one could see that the amount of glycogen granules increased in the zinctreated samples, and the size of each granule seemed smaller than that of control cells. In stressed photosynthetic organisms, it is common an increase in energy and carbon storage structures, such as glycogen. 


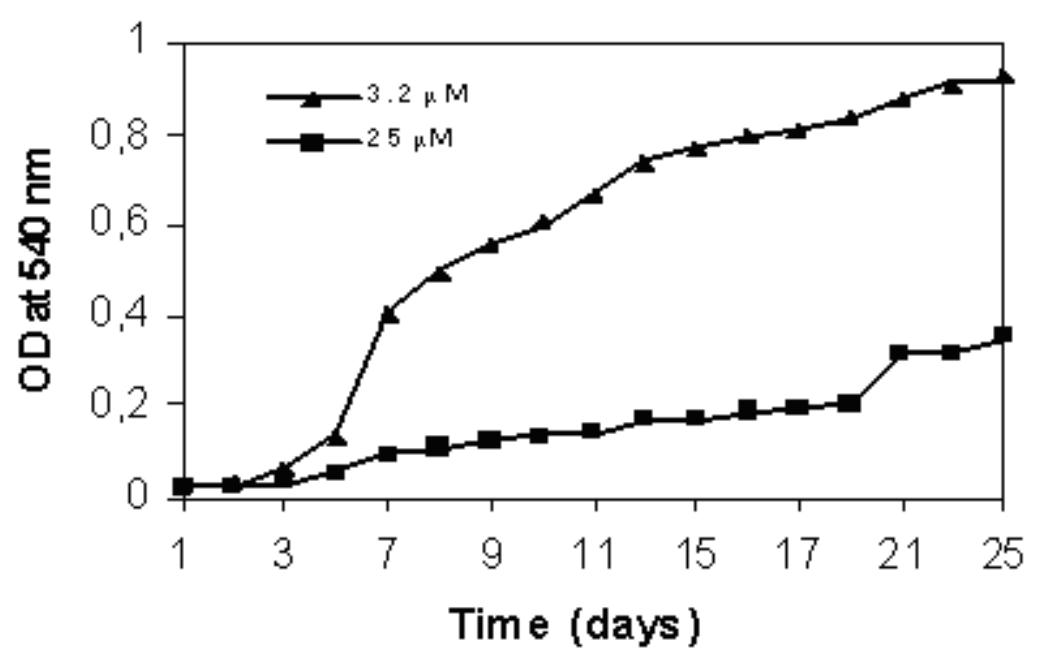

Figure 1 - Growth curves of Synechocystis aquatilis NPBS-3 grown on ASM-1 medium under $3.2 \mu \mathrm{M}$ (control) and $25 \mu \mathrm{M}$ of $\mathrm{ZnCl}_{2}$.
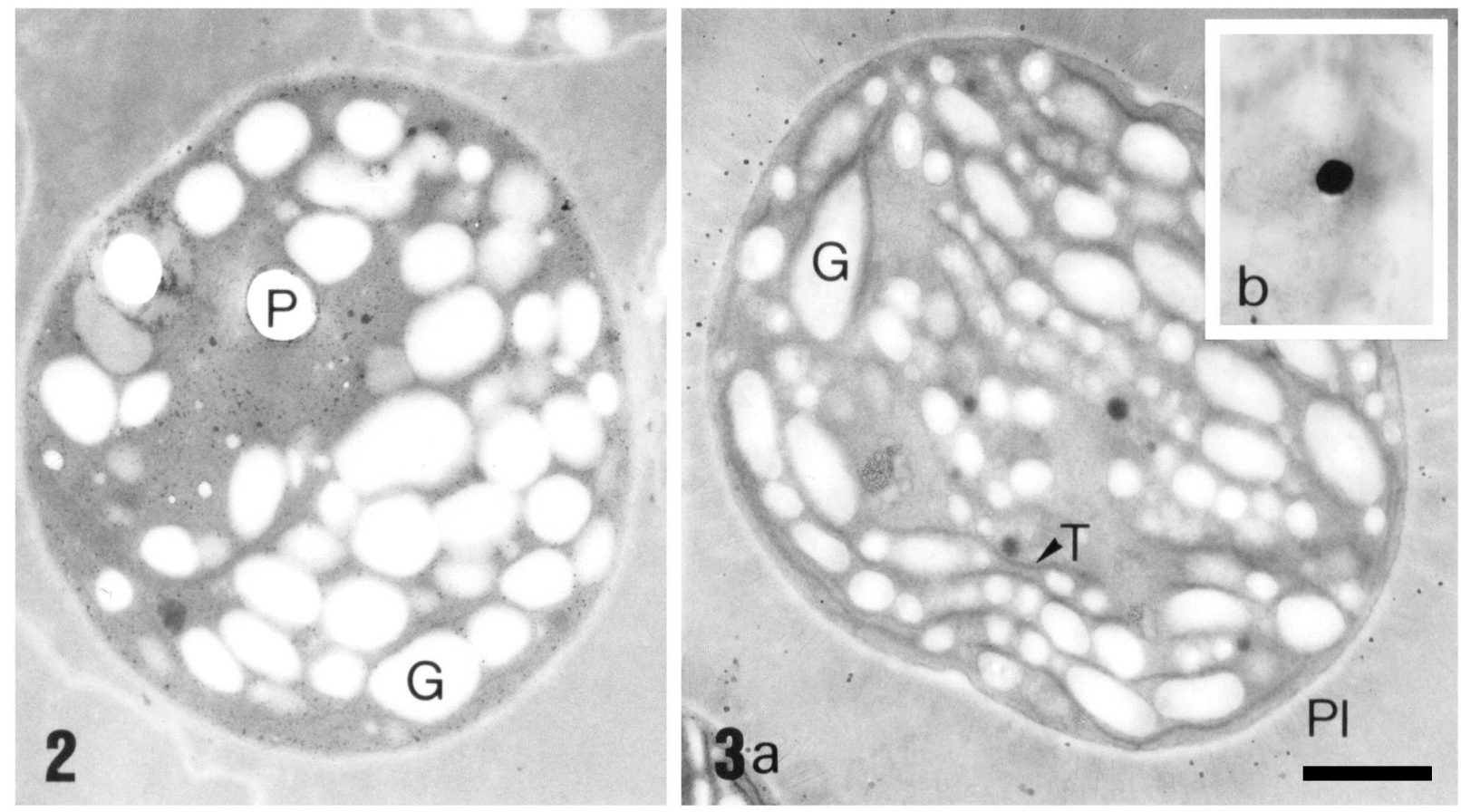

Figure 2 - Transmission electron micrograph of Synechocystis aquatilis NPBS-3 cells in control growth conditions. (P) Hole in the section occupied previously by a polyphosphate body and $(\mathrm{G})$ glycogen granules are shown. Bar $=0.5 \mu \mathrm{m}$.

Figure 3 - (a) Transmission electron micrograph of Synechocystis aquatilis NPBS-3 cells grown on $25 \mu \mathrm{M}$ Zn. (T) Thylakoid membranes, (G) glycogen granules and (PI) pilli. Bar = $0.5 \mu \mathrm{m}$. (b) Insert shows an ultrathin section containing one polyphosphate granule embedded in the hydrophilic resin nanoplast. $\mathrm{Bar}=0.38 \mu \mathrm{m}$. 


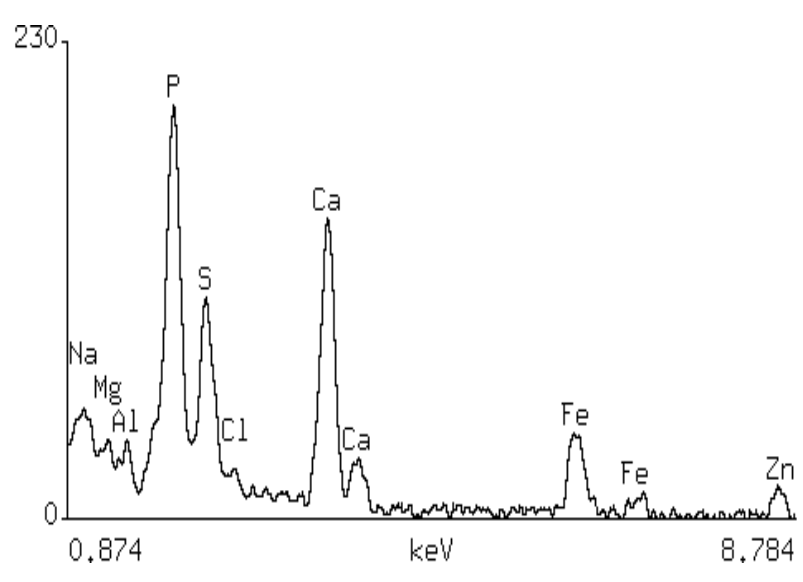

Figure 4 - Energy-dispersive X-ray analysis of a polyphosphate body of a zinc-treated cell after subtracting the background.

This result is in agreement with those of Andrade et al. (1993) who found an increase in photosynthetic activity for Synechocystis cells treated with zinc. Although not clearly visible in the electronmicrograph on Fig. 3a, polyphosphate granules were found in cells grown on zinc chloride (e.g. fig. 3b). Based on the findings of other authors, we decided to check for the presence of zinc in the cytoplasm and in the polyphosphate granules.

Energy-dispersive X-ray analysis (EDXA) showed the presence of zinc in the polyphosphate bodies of some zinc-treated cells. Fig. 4 shows the net spectra of a polyphosphate body, after subtracting the background. A discrete zinc peak was present, and also the peaks of phosphorus, sulphur, calcium, iron, sodium, magnesium, and aluminium. Zinc was not found in other regions of the cell. The presence of zinc in this structure could represent a way of detoxifying the excess metal. EDXA of granules of control cells showed the same elements, with the exception of zinc. As previously stated, these cells could accumulate about 20 times the amount of zinc of the control cells (Andrade and Pfeiffer, 1999). As the control cells had no detectable zinc when examined by EDXA, it was expected small zinc peaks in zinctreated cells.

In prokaryotic organisms, metal detoxification occurs by (i) enzymatic reduction or oxidation of the metal, which is converted to a less toxic form; (ii) methylation and diffusion of the methyl-metal through the membrane; (iii) active efflux systems; and (iv) complexation (Nies, 1992; Wood and
Wang, 1983). Metals can be complexed by proteins like metallothioneins (Robinson et al., 1990), polymers of the cell wall and capsule (Beveridge, 1981; 1989) or by polyphosphate granules (Baxter and Jensen, 1980b; Jensen et al., 1982a; Rai et al., 1990; Keasling and Hupf, 1996; Gonzalez and Jensen, 1998).

The cyanobacterium Synechocystis aquatilis NPBS-3 is no doubt tolerant to zinc (Andrade and Pfeiffer, 1999). This tolerance could be a result of natural selection in the bay where it comes from. This microorganism had been extensively investigated before for a metallothionein gene similar to the smtA of Synechococcus cells (Robinson et al., 1990). No conclusions came up for the existence of a similar gene (Andrade, 1997). Surprisingly, Synechocystis from Sepetiba Bay tolerates a higher concentration of zinc (it survives up to $32 \mu \mathrm{M}$ of $\mathrm{ZnCl}_{2}$, data not shown) than Synechococcus for which this highly specialized metal detoxification mechanism, an specific metallothionein, has been reported (Turner et al, 1993). The higher zinc concentration that Synechococcus can tolerate is $14 \mu \mathrm{M}$.

Besides the presence of zinc, the polyphosphate granules of Synechocystis aquatilis NPBS-1 presented phosphorus, sulphur, magnesium, sodium and calcium, common components of polyphosphate granules (Webster et al., 1984), and also aluminium and iron, less common components of these structures (Spring et al., 1998; Lins and Farina, 1999).

Such granules have been proposed to have a role in chelating metals such as calcium, potassium and magnesium (Wood and Clark, 1988). However, some authors have related them to the detoxification of heavy metals in cells of prokaryotic and eukaryotic organisms. The cyanobacterium Plectonema boryanum exposed to $20 \mathrm{ppm}$ of zinc, aluminium, manganese or lead for $1 \mathrm{~h}$ showed high amounts of these metals inside polyphosphate bodies (Torres et al., 1998). Studies in Anabaena cylindrica have shown the accumulation of aluminium in polyphosphate granules and claimed the participation of these structures as a detoxification mechanism (Petterson et al., 1985). Stereologic studies of zinc-exposed Anabaena variabilis showed that high concentrations of zinc caused an increase in the relative volume of these structures (Rachlin et al., 1985). The same was found for cadmiumexposed Plectonema boryanum (Rachlin et al., 1982). Zinc was detected in the polyphosphate 
granules of zinc-exposed Chlorella saccharophila, but not in these structures of Navicula incerta and Nitzschia closterium; in contrast, lead was found in the polyphosphate granules of these three algae species (Jensen et al., 1982b). Besides, Hashemi et al. (1994) found that Anabaena variabilis cells with large pools of polyphosphate were more resistant to metal even though the metals were not localized in the polyphosphate granules.

There are no doubts that polyphosphate granules are certainly involved in metal detoxification by Synechocystis aquatilis NPBS-3. If the polyphosphate granules sequestrate zinc and these structures are not membrane-bounded in bacteria, the free $\mathrm{Zn}^{2+}$ in the cytoplasm will decrease. This will alleviate the cell of metal contamination.

\section{CONCLUSIONS}

Metal detoxification mechanisms as polyphosphate granules, although less sophisticated, seem to be more effective than a metallothionein, which is sometimes very specific for binding only one metal. The non-specificity of the granules gives them the ability of binding many different metals. Although we investigated zinc only, it is known that the bay where Synechocystis was isolated is also contaminated with cadmium, lead and chromium (Penna Franca et al., 1984). The mechanism proposed here seems to be effective for surviving in a metal polluted environment and could be the reason for selection of metal-tolerant species such as Synechocystis aquatilis NPBS-3. Hence, we suggest further investigations on the role of polyphosphate granules of this cyanobacterium in the presence of these other pollutants of the bay.

\section{ACKNOWLEDGMENTS}

We are grateful to CNPq/PRONEX and FAPERJ for financial support. We thank the Laboratory of Cell Ultrastructure Hertha Meyer (UFRJ) for microscopy facilities.

\section{RESUMO}

O presente trabalho descreve o acúmulo de zinco em grânulos de polifosfato da cianobactéria
Synechocystis aquatilis NPBS-1 como mecanismo de detoxificação de metais pesados. $\mathrm{O}$ microrganismo foi isolado de uma baía contaminada com metais, a Baía de Sepetiba, próxima à cidade do Rio de Janeiro. As células foram cultivadas em $25 \mu \mathrm{M}$ de cloreto de zinco e preparadas para microscopia eletrônica e análise de dispersão de energia de raios-X. Algumas mudanças morfológicas ocorreram após a exposição ao zinco. A principal modificação foi o aumento no número de grânulos de glicogênio, como provável mecanismo fisiológico de adaptação. Os grânulos de polifosfato continham fósforo, enxofre, cálcio, ferro e zinco. O acúmulo de zinco nesses grânulos parece ser um mecanismo efetivo de detoxificação do metal para sobrevivência da cianobactéria na baía. Devido à sua não-especificidade na captação de cátions metálicos, os grânulos podem ser igualmente efetivos em acumular outros eventuais metais em excesso, além do zinco.

\section{REFERENCES}

Andrade L. (1997), Investigação da tolerância a zinco na cianobactéria Synechocystis aquatilis NPBS-3 da Baía de Sepetiba (RJ, Brasil). PhD thesis, Universidade Federal do Rio de Janeiro, Brazil.

Andrade L.; Azevedo S.M.F.O. and Pfeiffer W.C. (1993), Primary production and photosynthetic activity of 3 phytoplankton species cultivated under high Zn concentrations. Fresenius Envir. Bull., 2, 503-508.

Andrade L.; Azevedo S.M.F.O. and Pfeiffer W.C. (1994), Effects of high zinc concentrations in phytoplankton species from Sepetiba Bay (Brazil). Arq. Biol. Tecnol., 37, 3, 655-666.

Andrade L. and Pfeiffer W.C. (1999), Zinc retention by a cyanobacterium from Sepetiba Bay, RJ, Brazil. Ciência e Cultura, 51, 46-49.

Baxter, M. and Jensen, T. (1980a), A study of methods for in situ X-ray energy dispersive analysis of polyphosphate bodies in Plectonema boryanum. Arch. Microbiol,. 126, 213-215.

Baxter, M. and Jensen, T. (1980b), Uptake of magnesium, strontium, barium and manganese by Plectonema boryanum (Cyanophiceae) with special reference to polyphosphate bodies. Protoplasma, 104, 81-89.

Beveridge, T.J. (1981), Ultrastructure, chemistry, and function of the bacterial cell wall. Int. Rev. Cytol., 72, 29-305. 
Beveridge, T.J. (1989), Role of cellular design in bacterial metal accumulation and mineralization. Annu. Rev. Microbiol., 43, 147-171.

Gonzalez, H. and Jensen, T.E. (1989), Nickel sequestering by polyphosphate bodies in Staphylococcus aureus. Microbios, 93, 179-185.

Gorham P.R.; McLachlan J.; Hammer U.T.; Kim W.K. (1964), Isolation and culture of toxic strains of Anabaena flos-aquae (Lyng.) de Bréb. Verh. Internat. Verein. Limnol., XV, 796-804.

Hashemi F.; Leppard G.G. and Kushner D.J. (1994), Copper resistance in Anabaena variabilis: effects of phosphate nutrition and polyphosphate bodies. Microb. Ecol., 27, 159-176.

Jensen, T.E.; Baxter, M.; Rachlin, J.W. and Jani, V. (1982a), Uptake of heavy metals by Plectonema boryanum (Cyanophyceae) into cellular components, especially polyphosphate bodies: an X-ray energy dispersive study. Environ. Pol. A, 27, 119-127.

Jensen, T.E.; Rachlin J.W.; Jani, V. and Warkentine, B. (1982b). An x-ray energy dispersive study of cellular compartimentalization of lead and zinc in Chlorella saccharophila (Chlorophyta), Navicula incerta and Nitzschia closterium (Bacillariophyta). Environ. Exp. Bot., 22, 3, 319-328.

Keasling, J.D. and Hupf G.A. (1996), Genetic manipulation of polyphosphate metabolism affects cadmium tolerance in Escherichia coli. Appl. Envir. Microbiol., 62, 2, 743-746.

Lins, U. and Farina, M. (1999), Phosphorus-rich granules in uncultured magnetotatic bacteria. FEMS Microbiol. Lett., 172, 23-28.

Nies, D.H. (1992), Resistance to cadmium, cobalt, zinc and nickel in microbes. Plasmid, 27, 17-28.

Penna Franca, E.; Pfeiffer, W.C.; Fizman, M. and Lacerda, L.D. (1984), Aplicabilidade da análise pelos parâmetros críticos usualmente empregada para instalações nucleares no controle da poluição do ambiente marinho por metais pesados. Ciência $e$ Cultura, 36, 215-219.

Petterson, A.; Kunst, L.; Bergman, B. and Roomans, G.M. (1985), Accumulation of aluminium by Anabaena cylindrica into polyphosphate granules and cell walls: an X-ray energy-dispersive microanalysis study. J. Gen. Microbiol., 131, 2545-2548.

Rachlin, J.W.; Jensen, T.E.; Baxter, M. and Vandana, J. (1982), Utilization of morphometric analysis in evaluating response of Plectonema boryanum (cyanophyceae) to exposure to eight heavy metals. Arch. Environ. Contam. Toxicol., 11, 323-333.

Rachlin, J.W.; Jensen, T.E. and Warkentine, B.E. (1985), Morphometric analysis of the response of Anabaena flos-aquae and Anabaena variabilis (Cyanophyceae) to selected concentrations of zinc. Arch. Environ. Contam. Toxicol., 14, 395-402.
Rai, L.C.; Jensen, T.E. and Rachlin, J.W. (1990), A morphometric and X-ray energy dispersive approach to monitoring $\mathrm{pH}$-altered cadmium toxicity in Anabaena flos-aquae. Arch. Environ. Contam. Toxicol., 19, 479-487.

Robinson, N.J. (1989), Algal metallothioneins: secondary metabolites and proteins. J. Appl. Phycol., 1, 5-18.

Robinson, N.J.; Gupta, A.; Fordham-Skelton, A.P.; Croy, R.R.D.; Whitton, B.A. and Huckle, J.W. (1990), Prokaryotic metallothionein gene characterisation and expression: chromosome crawling by ligation-mediated PCR. Proc. R. Soc. Lond. B, 242, 241-247.

Simkiss, K. (1993), Amorphous minerals in biology. Bull. l' Inst. Oceanogr. Monaco, 14, 1, 49-54.

Simmons, J.; Simkiss, K.; Taylor, M.G. and Jarvis, K.E. (1994), Crab biominerals as environmental monitors. Bull. l'Inst. Oceanogr. Monaco, 14, 1, 225-230.

Spring, S.; Lins U.; Amman R.; Schleifer, K.; Ferreira, L.; Esquivel, D. and Farina, M. (1998), Phylogenetic affiliation and ultrastructure of uncultured magnetic bacteria with unusually large magnetosomes. Arch. Microbiol., 169, 136-147.

Taylor, M.G. and Simkiss, K. (1993), Cations substitution in phosphate biominerals. Bull. l'Institut. Oceanogr. Monaco, 14, 1, 75-79.

Torres, M.; Goldberg, J. and Jensen, T.E. (1998), Heavy metal uptake by polyphosphate bodies in living and killed cells of Plectonema boryanum (Cyanophyceae). Microbios, 96, 141-147.

Turner, J.S.; Morby, A.P.; Whitton, B.A.; Gupta, A. and Robinson, N.J. (1993), Construction and characterisation of $\mathrm{Zn}^{+2} / \mathrm{Cd}^{+2}$ hypersensitive cyanobacterial mutants lacking a functional metallothionein locus. J. Biol. Chem., 268, 44944498.

Webster, J.A., Fay, D.D., Costa, J.L., Jones, P. M. and Hugh, R. (1984), Elemental composition of bacterial metachromatic inclusions determined by electron microprobe X-ray analysis. J. Bacteriol., 158, 441446.

Wood, H.G. and Clark, J.E. (1988), Biological aspects of inorganic polyphosphates. Ann. Rev. Biochem,. 5, 235-260.

Wood, J.M. and Wang, H-K. (1983), Microbial resistance to heavy metals. Environ. Sci. Technol., 17, $12,582-590$. 